\title{
The Effect of Organizational Culture \& Job Satisfaction On Turn Over Intention, With Organizational Commitment As a Mediating Variable (Study Case At PT SAS Kreasindo Utama)
}

\author{
Nico Alexander Vizano, Aris Setiyani, Lenny Nawangsari \\ Mercu Buana University, Indonesia \\ nickvizano@gmail.com,setiyani.aris@gmail.com,lenny.nawangsari@gmail.com
}

\begin{abstract}
Currently high levels of turnover intentions have become a serious problem for many companies, therefore it is necessary to investigate the cause of its. The cause of turn over intention should be prevented from interfering with the productivity of the company. The purpose of this study was to investigate the effect of organizational culture, employee satisfaction on turn over intention. Organisational Commitment used to mediating variable. Population of the sample from PT SAS Kreasindo utama is 230 people and 150 samples obtained using the Slovin formula. Methods of data analysis used statistical analysis with Partial List Square (PLS). The results showed that organizational culture have a positive effect on organizational commitment ,job satisfaction have a positive effect on organizational commitment, Organizational culture have a negative effect on turn over intention, Job satisfaction have a negative effect on turn over intention, Organizational Commitment have a negative effect to turn over intention, Organizational Culture has a negative and significant effect on turn over intention through Organizational Commitment and Job Satisfaction has a negative and significant effect on turn over intention through Organizational Commitment.
\end{abstract}

Keywords: Organizational Culture, Job Satisfaction, Organizational Commitment, Turn Over Intention, Partial List Square (PLS)

\section{INTRODUCTION}

The performance of a company is determined by the condition and behavior of employees owned by the company. The phenomenon that often happens is the performance of a company that has been so good can be damaged, either directly or indirectly, by various employee behaviors that are difficult to prevent. One form of employee behavior is the desire to move (turnover intentions) that led to the employee's decision to leave his job. Given the high turnover rates in the company, the more potential costs will arise, whether the cost of training has been invested in employees, the level of performance that must be sacrificed, and the cost of recruitment and retraining (Toly, 2001).

In some cases, turnover is required by companies primarily for low-performing employees (Hollenbeck and Williams 1986), but the turnover rate should be strived not to be so high that firms still have the opportunity to benefit from the improved performance of new employees greater than the recruitment costs incurred by the organization. Turnover intentions should be addressed as an important human phenomenon and behavior in organizational life from both an individual and a social point of view, given that the rate at which employees move will have a significant impact on the company and the individual (Suartana 2000). 
PT. SAS Kreasindo Utama is a Producer of Contemporary Furniture Based Wood has one of the mission that is developing a strong and mindset industrial personnel as one of the company's assets in order to support the company's vision. In order to realize the vision and mission of the company in accordance with the Corporate Plan Long Term (Corporate Plan), has been implemented program development of human resource professional qualification consistently through integrated human resource management system.

Tabel 1. Turn Over Intention of PT. SAS Kreasindo Utama

\begin{tabular}{llc}
\hline Note & $\begin{array}{l}\text { Amount of } \\
\text { Reespondents }\end{array}$ & Percentage \\
\hline $\begin{array}{l}\text { The amount of employee for 1 division in PT. SAS } \\
\text { Kreasindo Utama }\end{array}$ & 43 & 100 \\
Left from company & 12 & 27,90 \\
\hline
\end{tabular}

Source : PT. SAS Kreasindo Utama, 2009

High turnover rates cause the costs incurred by the company to hire and train new employees to be high. The existing work situation also becomes less fun because too frequent turnover of personnel that incidentally led to continuous adjustment. From this phenomenon, researcher do the research to investigate the variables that influence on turn over intention.

\section{REVIEW OF LITERATURE}

Turn Over Intention. Intention is a function of three basic determinants, namely the first attitudes of the individual to behavior, the second is the individual's perception of social pressure to do or not to do the behavior, and the third is the aspect of behavioral control that lived (Azwar, 1995). The explanation of the emergence of specific behavior in individuals is explained by Ajzen and Fishbein in the form of a theory called the theory of planned behavior. This theory seeks to predict and explain human behavior in a particular context. According to Ajzen and Fishbein, the attitude and personality of a person influences certain behaviors only if indirectly influenced by several factors closely related to behavior (Ajzen, 1991) In the form of schemes, can be described as follows:

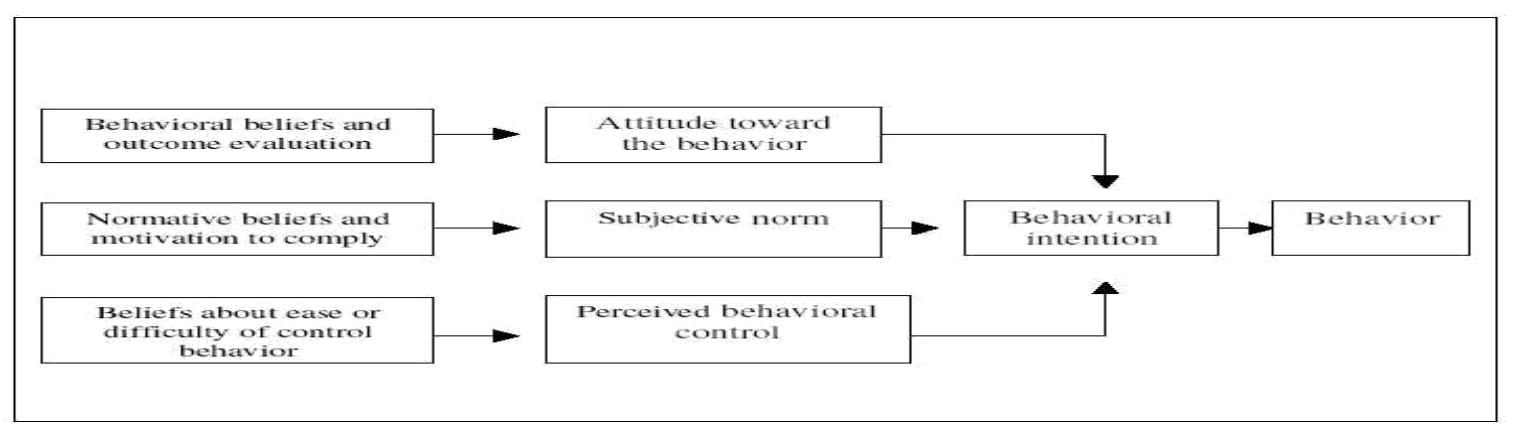

Picture 1. Theory of Planned Behavior (Ajzen, 1991) 
Janjua et al (2016) In his research argued that the organization realizes that employees are an important asset of the company, therefore need to be retained so as not to leave his job to move to another company. Therefore they create and implement organizational management practices such as training and career development that not only keep their employees satisfied but still have a desire to work continuously in their company. Turnover rates should be monitored and considered to be very important in the formulation of policies concerning human resources and organizational factors. This will assist management in retaining their employees. Zhang (2016) in the conclusion say that employee turnover is an important field in the research of human resource management, this article summarizes the current research results from personal factor, organization and work factor, social and economic factor these three aspects that help others who are interested in employee turnover influence factors have a comprehensive understanding.

Choi et al (2014) in the research finding that Significant differences in job satisfaction and turnover intention were found according to organizational culture types. The factors that enhance job satisfaction were found to be higher innovation-oriented organizational culture. Lower turnover intention was shown to be positively associated with relationshipor innovation oriented organization culture.

Job Satisfaction. Job satisfaction for employees is needed, because employee job satisfaction will increase productivity. The dissatisfaction of employees in the work will bring unfavorable consequences for the company as well as for the employees themselves. Wexley and Yukl (1977) in Novliadi (2007) argue that dissatisfaction will lead to two kinds of behavior: turnover or aggressive behavior (sabotage, deliberate misconduct, dispute between employee and superiors as well as strikes) resulting in decreased productivity. In general, employees who are not satisfied and have a turnover will leave the job (Mobley, 1986 in Novliadi, 2007). Based on the studies conducted, showed that the turnover rate is influenced by the job satisfaction of a person. The more dissatisfied a person will be with his work the stronger his drive to turnover. Dissatisfaction that causes turnover has many aspects, among them are dissatisfaction with company management, working conditions, quality of supervision, reward, salary, promotion, and interpersonal relationships.

Turnover is a phenomenon that exists at all levels in almost all kind of organizations. It is usually caused by the variation in Job satisfaction. Akhtar et al, (2016) in the research have a finding that Overall result suggesting that Turnover intension is significantly negative correlated with factors such as job satisfaction \& remuneration. Majority of the faculty members are intending to quit present job and looking for a new one although they are satisfied with their present job. Yousef (2017) In the results of the research says that indicated that employees in the investigated departments are highly satisfied with supervision and coworkers, whereas they are slightly satisfied with work conditions and job security, but they have low satisfaction with pay and promotion facets of the job.

In other research, Belias \& Koustelios (2014) says that Job satisfaction refers to the employees' perceptions of their working environment, relations among colleagues, earnings and promotion opportunities. The review shows that contemporary job related phenomena like job satisfaction are related to their perceptions of their working environment, relations with colleagues, institution aims and strategies and success criteria.

Organizational Culture. Organizational culture is a system of shared meanings, values and beliefs within an organization that is a reference to act and differentiate one 
organization from another (Mas'ud, 2004). Organizational culture then becomes the main identity or character of the organization maintained and maintained (Mas'ud, 2004). A strong culture is a very useful tool for directing behavior, because it helps employees to do a better job so that every employee early in his career needs to understand the culture and how it is implemented.

Robbin (2001) suggests a strong organizational culture has a considerable effect on employee behavior and directly reduces turnover. In a strong culture, the core values of an organization or company are deeply held and embedded in all of its employees. The more employees who receive these values and the greater commitment to them; the stronger the corporate culture will be. A strong culture will shape the company's cohesiveness, loyalty and commitment to its employees, which will reduce the employee's desire to leave the organization or company.

Organizational Commitment. Understanding "Organizational commitment is a worker's feelings and attitudes about the entire work organization" means organizational commitment is all the feelings and attitudes of employees to all things related to the organization where they work, including on their work (Riggio, 2000). According to Robbins (2001) commitment to the organization is a situation where an employee sides with an organization and its goals, and intends to maintain membership in the organization. In the research $\mathrm{Fu} \&$ Despandhe (2013) says that Job satisfaction had significant direct impact on organizational commitment, through which it also had a significant indirect impact on job performance. Finally, organizational commitment had a significant direct impact on job performance.

Wang et al (2017) We examined the mediating role of organizational commitment between psychological contract and turnover intention; the results of the study shows that organizational commitment plays a full mediating role in the relationship between transactional psychological contract and turnover intention, and plays a partial mediating role in the relationship between relational psychological contract and turnover intention.

Ruiz et al (2017) In the results of their research show that three dimensions of benefit satisfaction contribute to the development of Organizational support, and that Organizational support mediates their effects on organizational commitment. However, only benefit determination and benefit administration satisfaction have an effect on turnover intention, through the mediation of Oganizational Support and organizational commitment.

Objective Of This Study. The major objective of this research are: (1) To Investigate the effect of Organizational Culture have an impact on turn over intention; (2) To Investigate the effect of Job Satisfaction have an impact on turn over intention;(3) To Investigate the effect of Organizational Commitment as a mediating variable to adjust a positive impact of organizational culture and job satisfaction on turn over intention

\section{METHOD}

This study used questionnaires as the instrument for data collection. As a descriptive survey research, the study involved of supervisor level 4 . The population in this study is 230 , and the sample size was determined as follows:

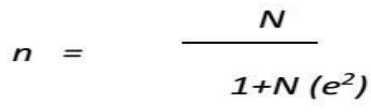


Where:

$\mathrm{N}$ : sample size to be determined

$\mathrm{N}$ : Population of supervisor level

E: Error margin $(0.05)$

\section{1: Content Value}

The calculation result for sample size as follow :

$$
\mathrm{N}=\frac{\underline{230}}{1+230(0.05)^{2}}
$$

= 146 Sample, from this calculation, researcher used 150 questioner for distributed to respondent.

This research combined both primary and secondary data for support the analysis. Primary data comprises of data obtained by administering. Questionnaire directly to the respondents. Out of the 150 questionnaire that were administered, all of respondents were completed and retrieved thus showing a response rate of 100 percent. The secondary data were sourced from professional journals, books, thesis and publications in academic. The questionnaire was structured on five point -Likert scale with weights assigned to :

Strongly Agree $(\mathrm{SA})=5$, Agree $(\mathrm{AG})=4$, Undecided $(\mathrm{UND})=3$, Disagree $(\mathrm{DA})=2$, Strongly Disagree $(\mathrm{SD})=1$. After the questionnaires back from respondent, the data analysis used statistical analysis with Partial List Square (PLS).

Framework And Hypothesis. This research have 2 independent variable are Organizational Culture \& Job satisfaction, 1 mediating variable is Organizational Commitment and 1 dependent variable is turn over intention. Framework for this research as follows:

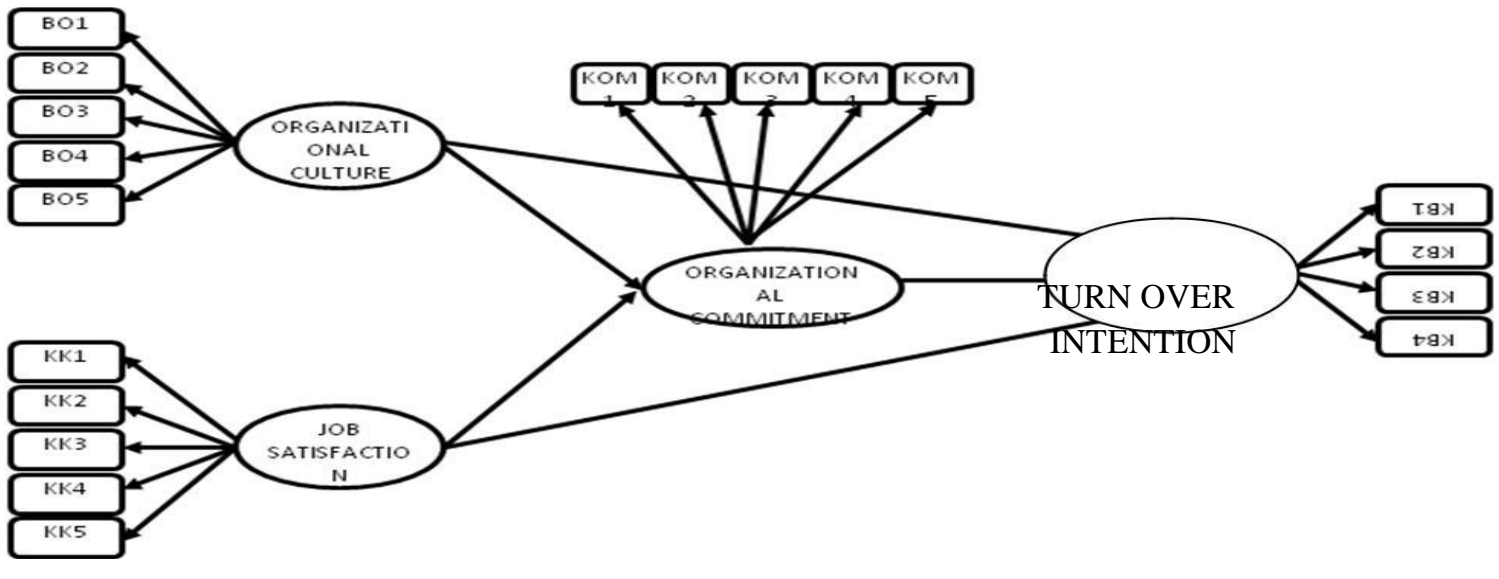


The hypothesis for this research as follows:

H1 : Organizational Culture has a positive impact on organizational commitment

H2 : Job satisfaction has a positive impact on organizational commitment

H3 : Organizational Culture has a positive impact on turn over intention

H4 : Job satisfaction has a positive impact on turn over intention

H5 : Organizational commitment has a positive impact to turn over intention

H6 : Organizational commitment booster the impact of organizational culture and job satisfaction on turn over intention

\section{RESULTS AND DISCUSSION}

Respondents Object Description. In this study, respondents who are used as research objects are permanent employees of the production division of PT. SAS Kreasindo Utama Tegal taken using the census method. Based on the technique, there are 150 employees as research sample.

Outer Model PLS Results. Outer model, with reflective indicator each measured by Convergent validity. The correlation between the reflexive indicator score and the latent variable score for this loading 0.5 to 0.6 is considered sufficient, since it is the initial stage of development of measurement scale and the number of indicators per construct is not large.

Table 2. Convergent validity Organizational culture

\begin{tabular}{|l|l|l|l|l|l|}
\hline & $\begin{array}{l}\text { original sample } \\
\text { estimate }\end{array}$ & $\begin{array}{l}\text { mean of } \\
\text { subsamples }\end{array}$ & $\begin{array}{l}\text { Standard } \\
\text { deviation }\end{array}$ & $\begin{array}{l}\text { T- } \\
\text { Statistic }\end{array}$ & Status \\
\hline CULTURE & & & & & \\
\hline BO1 & 0.896 & 0.907 & 0.043 & 20653 & Valid \\
\hline BO2 & 0.873 & 0.886 & 0.042 & 20,783 & Valid \\
\hline BO3 & 0.843 & 0.840 & 0.047 & 18.104 & Valid \\
\hline BO4 & 0.908 & 0.914 & 0.034 & 26.925 & Valid \\
\hline BO5 & 0.902 & 0.907 & 0.036 & 25.150 & Valid
\end{tabular}


Vizano, Setiyani,Nawangsari: The Effect of Orgnizaional Culture...

Table 3. Convergent validity Job satisfaction

\begin{tabular}{|l|l|l||l|l|l|}
\hline & $\begin{array}{l}\text { loiginal sample } \\
\text { estimate }\end{array}$ & $\begin{array}{l}\text { mean of } \\
\text { subsamples }\end{array}$ & $\begin{array}{l}\text { Standard } \\
\text { deviation }\end{array}$ & $\begin{array}{l}\text { T- } \\
\text { Statistic }\end{array}$ & Status \\
\hline SATISFACTION & & & & & \\
\hline KK1 & 0.830 & 0.842 & 0.040 & 20,850 & Valid \\
\hline KK2 & 0.856 & 0.851 & 0.032 & 27.050 & Valid \\
\hline KK3 & 0.927 & 0.926 & 0.020 & 46353 & Valid \\
\hline KK4 & 0.821 & 0.806 & 0.082 & 10,074 & Valid \\
\hline KK5 & 0.891 & 0.891 & 0.045 & 19,879 & Valid \\
\hline
\end{tabular}

Tabel 4. Convergent validity Organizational Commitment

\begin{tabular}{|l|l|l|l|l|l|}
\hline & $\begin{array}{l}\text { friginal sample } \\
\text { estimate }\end{array}$ & $\begin{array}{l}\text { mean of } \\
\text { subsamples }\end{array}$ & $\begin{array}{l}\text { Standard } \\
\text { deviation }\end{array}$ & $\begin{array}{l}\text { T- } \\
\text { Statistic }\end{array}$ & Status \\
\hline COMMITMENT & & & & & \\
\hline KOM1 & 0.906 & 0.920 & 0.035 & 26.214 & Valid \\
\hline KOM2 & 0.913 & 0.911 & 0.030 & 30.153 & Valid \\
\hline KOM3 & 0.960 & 0.960 & 0.014 & 70905 & Valid \\
\hline KOM4 & 0.887 & 0.880 & 0.085 & 10,482 & Valid \\
\hline KOM5 & 0.964 & 0.963 & 0.014 & 71.169 & Valid \\
\hline
\end{tabular}

Table 5. Convergent validity Intention to Move

\begin{tabular}{|c|c|c|c|c|c|}
\hline & $\begin{array}{l}\text { original sample } \\
\text { estimate }\end{array}$ & $\begin{array}{l}\text { mean of } \\
\text { subsamples }\end{array}$ & $\begin{array}{l}\text { Standard } \\
\text { deviation }\end{array}$ & Statistic & Status \\
\hline \multicolumn{6}{|c|}{ INTENTION } \\
\hline KP1 & 0.981 & 0.980 & 0.013 & 75.241 & Valid \\
\hline KP2 & 0.979 & 0.977 & 0.012 & 82.072 & Valid \\
\hline
\end{tabular}




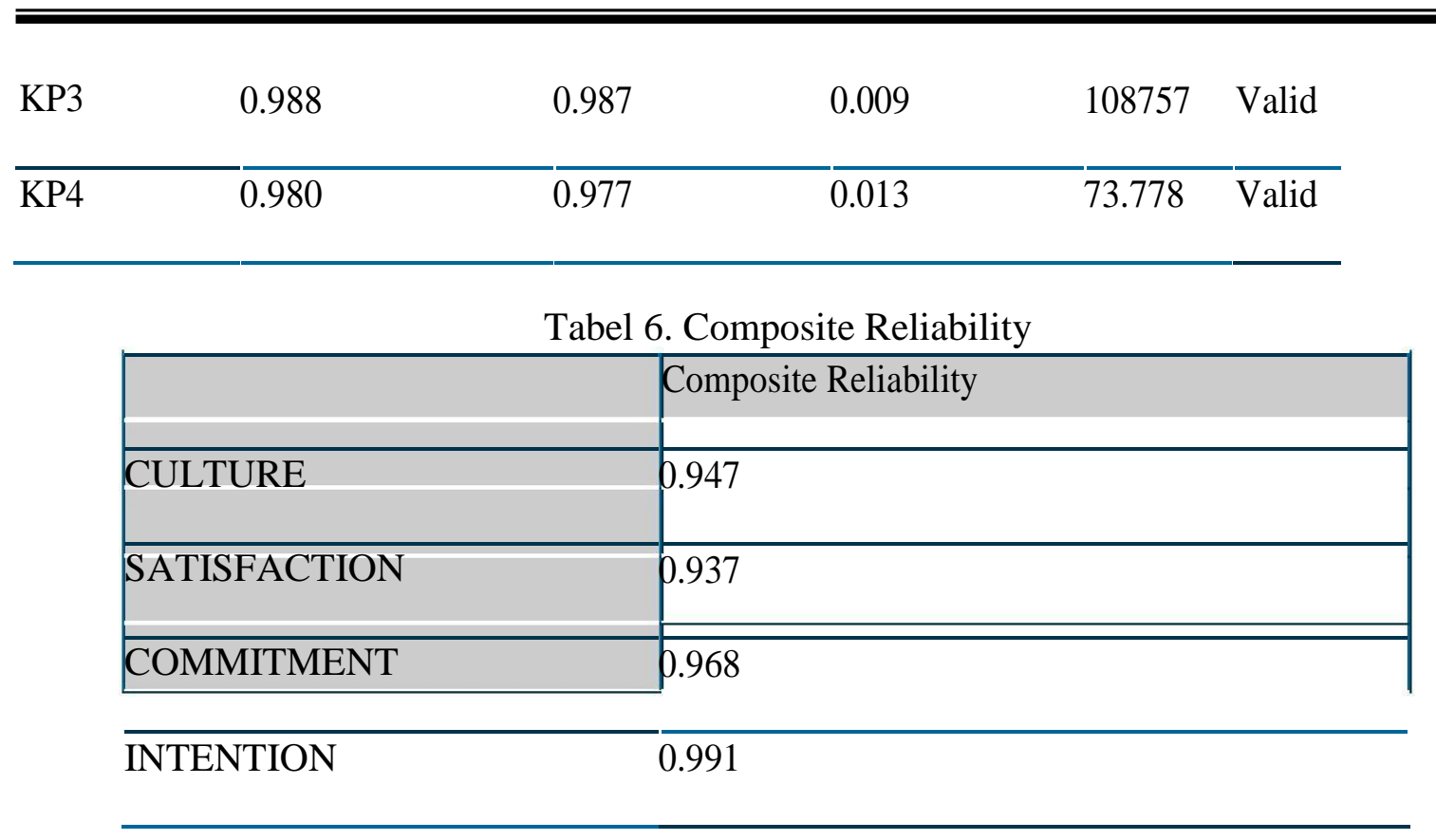

Table 7. Average Variance Extracted

Average variance extracted (AVE)

\begin{tabular}{|l|l|}
\hline CULTURE & 0.783 \\
\hline SATISFACTION & 0.750 \\
\hline COMMITMENT & 0.858 \\
\hline INTENTION & 0.964 \\
\hline
\end{tabular}

\section{Result Inner Model PLS}

Partial Least Square analysis is specially designed to overcome problems in linear regression such as correlation between high independent variables. Technically, PLS regression aims to produce a model that transforms a set of explanatory variables that correlate to a set of unrelated bar variables.

Based on result of analysis by using SmartPLS known magnitude coefficient of Organization Culture parameter (X1) to Moving Intention (Y 2) for - 0, 299 ; from Job Satisfaction (X2) to Moving Intention (Y2) of - 0,44 9, from Organizational Culture (X1) to Organizational Organizations (Y1) of 0, 352 ; of Job Satisfaction (X2) to K commitment of Organizational (Y1) of 0,3 and 66 of the $\mathrm{K}$ commitment of Organizational (Y1) to Moving Intention (Y2) of - 0.197. 
Results of Partial Least Square Analysis. The value of $t$ statistics from organizational culture to commitment organizational amount of 2.887 , job satisfaction to commitment organizational level of 2.662 , organizational culture to the Intention to move as much as 3,596, Satisfaction to the intention to move by 4.043 and from the commitment organizational to the intention to move performance of 1.710 . For more details can be seen in table 8 below

Table 8. Results for Inner Weights

\begin{tabular}{|c|c|c|c|c|}
\hline & $\begin{array}{l}\text { original sample } \\
\text { estimate }\end{array}$ & $\begin{array}{l}\text { mean of } \\
\text { subsamples }\end{array}$ & $\begin{array}{l}\text { Standard } \\
\text { deviation }\end{array}$ & $\begin{array}{l}\Gamma- \\
\text { Statistic }\end{array}$ \\
\hline CULTURE -> & & & & \\
\hline & 0.352 & 0.326 & 0.122 & 2.887 \\
\hline $\begin{array}{l}\text { SATISFACTION -> } \\
\text { COMMITMENT }\end{array}$ & 0.366 & 0.402 & 0.138 & 2.662 \\
\hline CULTURE -> & & & & \\
\hline Turnover Intention & -0.299 & 0.295 & 0.083 & 3.596 \\
\hline
\end{tabular}

SATISFACTION ->

$$
-0.449
$$

$-0.455$

0.111

4,043

Turnover Intention

COMMITMENT ->
$-0.197$
$-0.187$
0.115
1.710

Turnover Intention

Based on table 4 above it can be concluded that organizational culture be $\mathrm{r}$ direct influence to commitment with coefficient of 0,352 and significant at $5 \% \mathrm{t}$ value count $(2.887)>t$ table $(1,65)$. Cultural organizations also directly affects the intention to move with a coefficient of - 0, 29, 9 and significance at the $5 \%$ t value $(3,596)>t$ table $(1,65)$. Job satisfaction directly influence organizational commitment with coefficient of 0,366 and significant at the $5 \%$ t value $(2.662)>t$ table $(1,65)$. Job satisfaction also directly affects the intention to move with a coefficient of - 0,449 and significance at the $5 \% \mathrm{t}$ value (4.043)> $\mathrm{t}$ table $(1,65)$.

So it can be concluded that organizational culture directly affect the intention to move and also indirectly affect the intention to move through organizational commitment. So is job satisfaction influenced directly to the intention to move and also not directly effect on turnover intentions through organizational commitment. The magnitude of the coefficient of direct and indirect effects can be calculated as follows: 
Directly: Cultural organizations $========$ Intention to Move $=0,299$

Indirect: Organizational culture $=$ Commitment $=$ Intention to Move $=(0,352 \mathrm{x}$ $0,197)=0,069$

It turns out the influence of organizational culture on the intention to move directly greater than the indirect effect between organizational cultures against the intention to move through organizational commitment.

Directly: Satisfaction $==================$ Performance $=0,449$

Indirect: Satisfaction $==$ Commitment $==$ Intention to Move $=(0,366 \times 0,197)=0.0$ 72. On the second variable (organizational culture and job satisfaction) have a direct influence greater than the indirect effect against the intention to move through organizational commitment.

Tabel 9. R Square

\begin{tabular}{|r|c|}
\hline CULTURE & \\
\hline SATISFACTION & \\
\hline & R-square \\
\hline COMMITMENT & 0.326 \\
\hline INTENTION & \\
\hline
\end{tabular}

Based on the above it can be concluded that the output of the R-square value of 0,535 means that the regression model has a level of goodness-fit is good, which means that the variability of turnover intentions that can be explained by the three variables organizational culture, job satisfaction and organizational commitment of $53,5 \%$.

Discussion. The Influence of Organizational Culture Against Organizational Commitment. The results of this study provide empirical evidence that culture organization positively affects organizational commitment; means the better implementation of culture on an organization, the organizational commitment will also be higher. The results of this study are in line with Nasution's (2006) and Chairul Muriman, Idrus, et al (2008) studies which found empirical evidence that organizational culture has a significant positive effect on organizational commitment. According to Robbins (2001) organizational culture is a belief system and values shared by employees in a company, where the system that distinguishes the organization with other organizations. In a strong culture, the core values of an organization or company are deeply held and embedded in all of its employees. The more employees who receive these values and the greater commitment to them; the stronger the corporate culture is. Increased organizational culture is measured by indicators (a) devote all the ability, (b) clicking organize own work, (c) friendly , (d) initiative (initiative) and (e) meetings (meetings) on time will be able to increase organizational commitment.

The results of this study can be seen that employee indicators devote all its ability to work in the organization get the highest average value while the employee indicator as a 
member of the organization to be warm (friendly) in the association is the lowest rating so it needs special attention .

The Influence of Job Satisfaction To Organizational Commitment. The study provides empirical evidence that job satisfaction has positive influence on organizational commitment, meaning that the employees are satisfied at work, the organizational commitment will also be higher. This research is in line with Nasution (2006), Dewita Heriyanti (2007) and Chairul Muriman, Idsrus, et al (2008) who found empirical evidence that job satisfaction has a positive effect on organizational commitment.

According to Luthans (1998) job satisfaction is a person's positive and pleasant emotional state resulting from the assessment of a job or work experience. Job satisfaction is related to the physical in carrying out his job duties, the condition of his work environment, he also deals with his interactions with his colleagues, and the relationship system between them. In addition, job satisfaction is also related to the prospect of his work whether to give hope to develop or not. The more hope aspects are met, the higher the level of job satisfaction. Increased employee job satisfaction as measured by indicators (a) promotion opportunities, (b) salary, (c) co-workers, (d) the job itself and (e) supervisors will be able to increase organizational commitment. The results of this study can be seen that the indicators if doing a good job, it will be promoted to get the highest average value and salary indicator is in accordance with the responsibilities given is the lowest assessment so that need to get special attention .

The Influence of Organizational Culture on Turnover Intention. The results of this study provide empirical evidence that culture negatively affect organizational turnover intentions, means the better implementation of the organizational culture, the intention to move will be lower. The results of this study in line with research The results of Ferry Novliady (2007) stated that corporate culture associated with the intention of turnover. The relationship between corporate culture and employee turnover is negative, where the stronger the corporate culture, the lower the level of employee turnover intentions.

Robbin (2001) suggests a strong organizational culture has a considerable effect on employee behavior and directly reduces turnover. A strong culture will shape the company's cohesiveness, loyalty and commitment to its employees, which will reduce the employee's intention to leave the organization or company. Increased organizational culture is measured by indicators (a) devote all the ability, (b) clicking organize the work themselves, (c) friendly, (d) initiative (initiative) and (e) meeting (meeting) on time will be able to increase organizational commitment.

The results of this study can be seen that employee indicators devote all its ability to work in the organization get the highest average value while the employee indicator as a member of the organization to be warm (friendly) in the association is the lowest rating so it needs special attention.

The Effect of Job Satisfaction on Moving Intention. The study provides empirical evidence that job satisfaction negative effect on turnover intentions, which means that the employees are satisfied at work, then the lower turnover intentions. This research is in line with research of Eny Soelistyawati (2004), Nasution (2006) found empirical evidence that job satisfaction has a negative and significant effect on organizational change intention. 
Job satisfaction for employees is needed, because employee job satisfaction will increase productivity. The dissatisfaction of employees in the work will bring unfavorable consequences for the company as well as for the employees themselves. Wexley and Yukl (1977) in Novliadi (2007) suggest that dissatisfaction will lead to two behaviors: turnover or aggressive behavior (sabotage, deliberate misconduct, dispute between employee and superiors as well as strikes) resulting in decreased productivity. In general, employees who are not satisfied and have a turnover will leave the job (Mobley, 1986 in Novliadi, 2007) . Increased employee job satisfaction as measured by indicators (a) promotion opportunities, (b) salary, (c) co-workers, (d) the job itself and (e) supervisors will be able to decrease employee shifting intentions.

The results of this study can be seen that the indicators if doing a good job, it will be promoted to get the highest average value and salary indicator is in accordance with the responsibilities given is the lowest assessment so that need to get special attention.

The Effect of Organizational Commitment on Turnover Intention. The study provides empirical evidence that organizational commitment negatively affect turnover intentions, meaning that the higher organizational commitment, intention will move lower. This study is in line with the research of Eny Soelistyawati (2004) and Nasution (2006) found empirical evidence that organizational commitment has a negative and significant impact on the intention of moving organizations.

Organizational commitment is a condition in which employees are very interested in the goals, values, and objectives of the organization. Commitment to the organization means more than just formal membership. Because it includes the attitude of liking the organization and the willingness to seek high levels of effort for the interests of the organization for the achievement of goals (Steers in Kuntjoro, 2002).

According to Rusbult and Farrel (in Eny Soelistyawati, 2004) considers that commitment is a solution to the problem of organizational change, as most of the displaced employees have low organizational commitment. It appears that the important thing in the process of moving the organization is that there is a decrease in commitment even if there is a change of reward, etc. affecting job satisfaction also has a significant relationship with the intention to move

organization and although the changes affect the organizational commitment but the decrease of commitment seems to be the most important and directly affect the decisionmaking process to stay or move. Increased organizational commitment of employees as measured by indicators (a) working beyond the target, (b) equality of values, (c) being proud of being part of the organization, (d) inspiring organizations and (e) caring for organizational fate will be able to reduce the intention to move employees.

The results of this study can be seen that the indicator is willing to go the extra mile beyond what is expected for this organization to succeed in getting the highest average value and employee value indicators equal to the values of this organization is the lowest rating so that need to get special attention.

\section{CONCLUSIONS}

Conclusions. Based on the results of PLS test the discussion in this study can be concluded as follows: (1) Organizational culture has a positive effect on organizational commitment, meaning the better the application of organizational culture, and then organizational commitment will also be higher; (2) Job satisfaction has a positive effect on organizational 
commitment, meaning that more employees are satisfied with their work, and then organizational commitment will also be higher; (3) Organizational culture negatively affect the intention to move, meaning the Better the application of organizational culture, the intention to move will be lower; (4) Job satisfaction negatively affect the intention to move, meaning that more employees are satisfied with the job, the intention to move will be lower; (5) Organizational commitment negatively affects the intention to move, meaning that the higher the organizational commitment, the intention to move will be lower; (6) The results of indirect effect test proved Organizational Culture has a negative and significant effect on the intention to move through Organizational Commitment.; (7) The result of indirect effect test proved Job Satisfaction has a negative and significant effect on the Intention to Move through Organizational Commitment.

Theoretical implications. The theoretical and hypothetical theoretical framework developed in this study is based on various theories and results of previous research relating to organizational cultural variables, job satisfaction, and organizational commitment and shifting intention. The theoretical implications include:

1. Organizational culture as measured by indicators (a) devotes all capabilities, (b) organizing own work, (c) friendly, (d) initiative and (e) meetings on time will increase organizational commitment. Organizational culture has a positive effect on organizational commitment. The result of this research is in line with Nasution (2006) and Chairul Muriman, Idsrus, et al (2008). Organizational culture also negatively affects the intention to move. The results of this study are in line with research The results of research Ferry Novliady (2007)

2. Employee job satisfaction measured by indicators (a) promotion opportunities, (b) salary, (c) co-workers, (d) the job itself and (e) supervisors will be able to increase organizational commitment. Job satisfaction has a positive effect on organizational commitment. This research is in line with Nasution (2006), Dewita Heriyanti (2007) and Chairul Muriman, Idsrus, et al (2008). Job satisfaction also negatively affects the intention to move. This research is in line with the research of Eny Soelistyawati (2004), Nasution (2006)

3 Organizational organizational commitment as measured by indicators (a) working beyond the target, (b) equality of values, (c) being proud of being part of the organization, (d) inspiring organizations and (e) caring for organizational fate will be able to decrease employee shifting intentions. Organizational commitment has a negative effect on the intention to move. This research is in line with the research of Eny Soelistyawati (2004) and Nasution (2006).

Managerial implications. The managerial implications of this research are as follows: (1) The first managerial implications were made on organizational cultural variables. To be able to improve organizational culture, should be considered about employees as members of the organization that is able to be warm (friendly) in the association. (2) The second managerial implication is done on job satisfaction variable. To be able to improve job satisfaction should be paid attention on the provision of salary in accordance with job responsibilities. (3) The third managerial implication is done on organizational commitment variables. In order to increase organizational commitment, it should be noted about the similarity of employee values to the values that the organization has. 
The research has limitations in that suggest to be improve for further study; this research cannot be generalized for samples outside the study because the samples used are limited to permanent employees of the production division of PT. SAS Kreasindo Utama Tegal. In this study only examines the influence of organizational culture variables and job satisfaction on commitment and intention to move employees. Suggestion for further study to expand the object of research, not limited only to permanent employees of the production Division of PT. SAS Kreasindo Utama Tegal so that problems can be generalized. As well as necessary to add variables and development of research instruments adapted to the condition and environment of the object.

\section{REFERENCES}

Ajzen, Icek. (1991). The theory of Planned Behavior, Organizational Behavior and Human Decision Processes, Vol. 50, pp. 179-211

Akhtar, N., Awan, A. W. A., Anwar, M. A., Saeed, S., Ali, S., \& Qurban, M. (2016). "Impact of Job Satisfaction \& Remuneration on Turnover Intention: A Survey of (Private) Schools of (Okara) Pakistan". International Review of Management and Business Research, 5(2), 653-675.

Amstrong, (1994). The Art of HRD: Human Resource Management, London: Crest Publishing House

Barlett, (2001). The relationship between training and organizational commitment: A study in the health care field. Human Resource Development Quarterly. 12:335.

Belias, D., \& Koustelios, A. (2014). "Organizational culture and job satisfaction: A review". International Review of Management and Marketing, 4(2), 132.

Choi, S., Jang, I., Park, S., \& Lee, H. (2014). "Effects of organizational culture, selfleadership and empowerment on job satisfaction and turnover intention in general hospital nurses". Journal of Korean Academy of Nursing Administration, 20(2), 206-214.

de la Torre-Ruiz, J. M., Vidal-Salazar, M. D., \& Cordón-Pozo, E. (2017). "Employees are satisfied with their benefits, but so what? The consequences of benefit satisfaction on employees' organizational commitment and turnover intentions". The International Journal of Human Resource Management, 1-24.

Deshpande, R. \& J. Farley, (1999). "Executive Insights: Corporate culture and market orientation: Comparing Indian and Japanese firms", Journal of International Marketing, 7 (4), 111-127

Fu, W., \& Deshpande, S. P. (2014). "The impact of caring climate, job satisfaction, and organizational commitment on job performance of employees in a China's insurance company". Journal of Business Ethics, 124(2), 339-349.

Hofstede G., Neuijen B., Ohayu D. dan Sander G., (1990), "Measuring Organizational Cultures: A Qualitative Study Across Twenty Cases", Adminitrative Science Quarterly, 35 : $285-316$

Hollenbeck, Jr., dan C. R. Williams, (1986). Turnover Functionality versus Turnover Frequency: A Note on Work Attitudes and Organizational Effectivenes", Journal of Applied Psychology, 71, 606-611.

Kotter, John P. and Heskett, James L., (1998). Corporate Culture and Performance, New York:The Free Press, A Division of Mac Millan, Inc.

Luthans Fred, (1998). Organizational Behavior, Seventh Edition. McGraw-Hill, Inc 
Riggio, R, E, (2000) Introduction To Industrial/Organizational Psychology, Third Edition, Prentice Hall, New Jersey

Robbin, S.P., (2001). Organizational Behavior. Concepts, Controversies, Applications, New Jersey: Prentice-Hall, Inc

Schein, (1991). Organizational Behavior: Concept, Controversies and Aplications, 6Ih edition. New Jersey: Prentice-Hall, Inc.

Suartana, I. W., (2000). "Anteseden dan Konsekuensi Job Insecurity dan Keinginan Berpindah pada Internal Auditor", Tesis pada Magister Sains Universitas Gadjah Mada, Yogyakarta.

Xenikou, A. \& A. Furnham, (1996), “A correlational and factor analytic study of four questionnaire measures of organizational culture", Human Relations, 49 (3), 349371

Wang, Y., Li, Z., Wang, Y., \& Gao, F. (2017). "Psychological Contract and Turnover Intention: The Mediating Role of Organizational Commitment”. Journal of Human Resource and Sustainability Studies, 5(01), 21.

Yousef, D. A. (2017). Organizational Commitment, Job Satisfaction and Attitudes toward Organizational Change: A Study in the Local Government. International Journal of Public Administration, 40(1), 77-88.

Zhang, Y. (2016). "A review of employee turnover influence factor and countermeasure". Journal of Human Resource and Sustainability, Studies, 4(02), 85. 
Vizano, Setiyani,Nawangsari: The Effect of Orgnizaional Culture... 